\title{
Economic performance of coastal fisheries in Galicia (NW Spain): case study of the Cíes Islands
}

\author{
Giulia CAMBIÈ $^{1, a}$, Rosana OuRÉns ${ }^{1}$, Duarte F. VIDAL ${ }^{1}$, Sirka CARABEL $^{1}$ and Juan FreIRE ${ }^{1,2}$ \\ ${ }^{1}$ Univ. A Coruña, Fac. Ciencias, Grp Recursos Marinos \& Pesquerias, 15008 La Coruña, Spain \\ 2 Present address: Barrabés Next, C. Serrano 16-1, 28001 Madrid, Spain
}

Received 13 March 2012; Accepted 24 May 2012

\begin{abstract}
Biological, social and economic information is necessary in order to assess the effectiveness of fisheries management measures. Indicators of the economic performance of fishing vessels are a useful tool for improving management strategies and are necessary for the implementation of the ecosystem approach to fisheries management in European waters. However, they are usually difficult to obtain from official data, which are often biased, incomplete and/or lacking in spatial references. In this paper, a broad set of economic indicators is provided for the fleet operating around the Cíes Islands (NW Spain) during 2008, based on data obtained from interviews with fishers. Artisanal and purse seiners were the most representative segments of the study fleet. While artisanal vessels played an essential social role in Galician fishing communities, purse seiners were a fundamental economic segment as they had the highest profitability per vessel. Both segments appeared to be economically profitable in 2008, with a moderate rate of return on investment for artisanal vessels (around 7\%) and a high rate (around 13\%) for purse seiners. The present study identified the waters around the Cíes Islands as an essential fishing ground for the study fleet due to the high cash flow that it generated. As part of this area now belongs to a national marine park, our results represent a reference point for decision-makers and for the development of effective management strategies.
\end{abstract}

Keywords: Small-scale fisheries / Economic indicators / Economic performance / Fisheries management / Marine protected areas / Atlantic Ocean

\section{Introduction}

Fisheries worldwide are under pressure and management policies have often struggled to achieve sustainable fishing practices, economic efficiency and equity of access to resources (Cochrane 2000; Mora et al. 2009). The idea that industrial fisheries are solely responsible for this global crisis has been questioned by evidence showing the significant impact of small-scale fisheries (Zeller et al. 2007). However, despite their present problems, small-scale fisheries could be the only type of fisheries that, if appropriately managed, would be able to ensure the sustainable use of coastal resources (Pauly 2006). Moreover, because small-scale coastal fisheries contribute greatly to nutrition, food security and alleviating poverty, as well as playing an essential social role, their sustainable management has become an important aim and challenge for governments worldwide. Appropriate regulations need to be based on a thorough understanding of the current state of fisheries. Besides biological information on exploited fish stocks and fishing mortality rates, information on the cultural, environmental, political and socio-economic dimensions

\footnotetext{
a Corresponding author: giulia.cambie@gmail.com
}

of fisheries is also needed (Whitmarsh et al. 2000; Ünal and Franquesa 2010).

Combined fisheries and conservation objectives can be achieved by merging diverse management actions; however, this leads to a different set of problems, including the difficulty in ensuring that fishers adhere to the rules. Therefore, managers need objective arguments to support their decisions. Economic indicators back up these arguments because they can be used to estimate the effect of management policies and thus support the measures proposed. Estimating the economic performance of fishing vessels and the cash flow generated by the fishing industry is thus a fundamental prerequisite, firstly for formulating and then for implementing any management plan.

Currently, management decisions generally apply to specific fleet groups, and vessels have become the main focus of the regulations. Consequently, the economic analysis of fisheries and the related indicators also needs to be carried out at the level of the individual production unit (vessel). However, it is often difficult to access the data necessary for constructing these indicators, particularly for small-scale fisheries, for which there is less information (Worm et al. 2009). Currently, data on fishing activity are usually generated by the fishers themselves, as well as by fishery inspectors and biologists 
sampling catches at random (Griffiths et al. 2007). In spite of the appreciable advances made in recent years, fishery statistics and economic data are frequently inadequate for obtaining good spatial coverage. In fact, official information, when it does exist, is often biased and generally does not refer to the fishing ground where the vessels operate but only to the ports where they are based or the fishing cooperatives in which they are registered. The lack of catch and economic data collected in relation to fishing areas makes it difficult to formulate and implement spatial regulations, which have become a mainstay of fisheries management.

The problems listed above are common to all fisheries worldwide and thus it is urgently necessary to implement data collection methods that can fill in these gaps, especially in regions where the fishing activity plays an essential socioeconomic role.

In Europe, Galicia (NW Spain) is one of the regions with the highest socio-economic dependence on fishing, not only due to the high level of fish production and employment but also to the strong relationships between fisheries and other sectors of the local economy (Losada 2000). In this context the environmental impacts of the Galician fishing sector related to the entire value chain (from exploitation of the stocks to the greenhouse gas emissions for seafood production, processing, transport and consumption), are considerable and need to be reduced (Iribarren et al. 2010). Currently the Galician fleet represents $47.5 \%$ and $42.3 \%$ of the Spanish fleet in terms of number of boats and gross tonnage, respectively (Ministerio de Agricultura, Alimentación y Medio Ambiente 2011), and the small-scale coastal fisheries have the largest number of vessels and fishers. However, the effectiveness of the management policies in the region appears to be limited to shellfish exploitation, which is regulated through territorial users' rights and TAC/quota regulations. In fact, assigning dedicated access privileges, such as territorial fishing rights, to individual fishers or fishing communities often provides economic incentives to reduce their effort and exploitation rate and may also improve compliance and participation in the management process (Worm et al. 2009). All the other resources (demersal and pelagic stocks) are poorly managed off the Galician coast because the regulations, when they do exist, do not provide territorial users' rights and are often inadequate for the current status of the exploited stocks. This situation is worrying in the light of the growing evidence that many of the target stocks of coastal fisheries in Galicia are being overharvested (Freire and García-Allut 2000; Freire et al. 2002) or caught with methods that produce significant impact on the environment (Vázquez-Rowe et al. 2010). Therefore, the current state of management does not seem to conciliate the need to exploit fishery stocks with that of protecting the marine habitat and species. This difficulty is mainly caused by the lack of information on the fishing system of the region, such as data on fishing effort, catch statistics and the economic situation of the fleet. Moreover, the lack of spatial references for this information makes it difficult, if not impossible, to create appropriate management plans.

In the present study, the economic performance of the Galician fleet operating around the Cíes Islands was analyzed. As these islands are currently part of a national marine park, it is now essential to establish a sustainable fisheries management plan for this area. In this context our main aims were to: (i) provide economic information on the fishing fleet, describing its cost structure and economic performance; and (ii) estimate the cash flow generated by the fishing activity and identify parameters for assessing the economic viability of these fisheries. In order to achieve these goals we used a low-cost methodology that allowed us to estimate the economic indicators for both the individual production unit (vessel) and the fishing ground.

\section{Materials and methods}

\subsection{Fleet segments}

The fishing ground around the Cíes Islands belongs to the IXa ICES fishing area and includes the south part of National Land-Marine Park of the Atlantic Islands of Galicia (Fig. 1). This national park, established in 2002, is the only one in Galicia and the thirteenth established in Spain chronologically. The fishing fleet in the Cíes Islands is mainly composed of vessels from Ría de Vigo and a few boats from Ría de Pontevedra. The number of fishing vessels operating in Cíes Islands was estimated through a stepwise approach. First, a random sample of the fishers $(n=424)$ was asked the time they spent in Cíes Islands and the fishing gears usually employed in this area. Fishers were initially approached in the port of Cangas (the closest port to the Cíes Islands) and then through the ports located to the North and South, until no more boats working in Cíes Islands could be found (Fig. 1). The percentage of those vessels fishing around the Cíes Islands with at least one fishing gear was then compared with the official census of the Galician fleet (Xunta de Galicia 2009) in order to estimate the corresponding proportion of vessels operating in this area. This led to an estimate of 565 vessels fishing around the Cíes Islands for at least one month a year. The main base ports are Cangas, Moaña, Vigo, Redondela, Aldán, Baiona, Bueu, Marín, Arcade and $\mathrm{O}$ Grove (Fig. 1).

The fleet was divided into three main segments according to the Scientific, Technical and Economic Committee for Fisheries (STECF) of the European Commission and its data collection framework (DCF) used until 2010:

1. Vessels less than $12 \mathrm{~m}$ long combining mobile and passive gears (European code: PMP VL0012): in the present study we called this segment "artisanal".

2. Vessels between 12 and $24 \mathrm{~m}$ long using polyvalent passive gears (European code: PGP VL1224): we called this segment "polyvalent".

3. Vessels between 12 and $24 \mathrm{~m}$ long using a purse seine (European code: PEL VL1224): we called this segment "purse seiners".

Out of the 565 vessels that composed the fleet operating around the Cíes Islands, 515 were artisanal vessels, 15 polyvalent vessels and 35 purse seiners. In the present study the artisanal and polyvalent segments can be defined as small-scale fisheries due to the relatively small size of their vessels (generally less than $15 \mathrm{~m}$ long) as well as their coastal fishing activity, since they operate in the national fishing ground. 


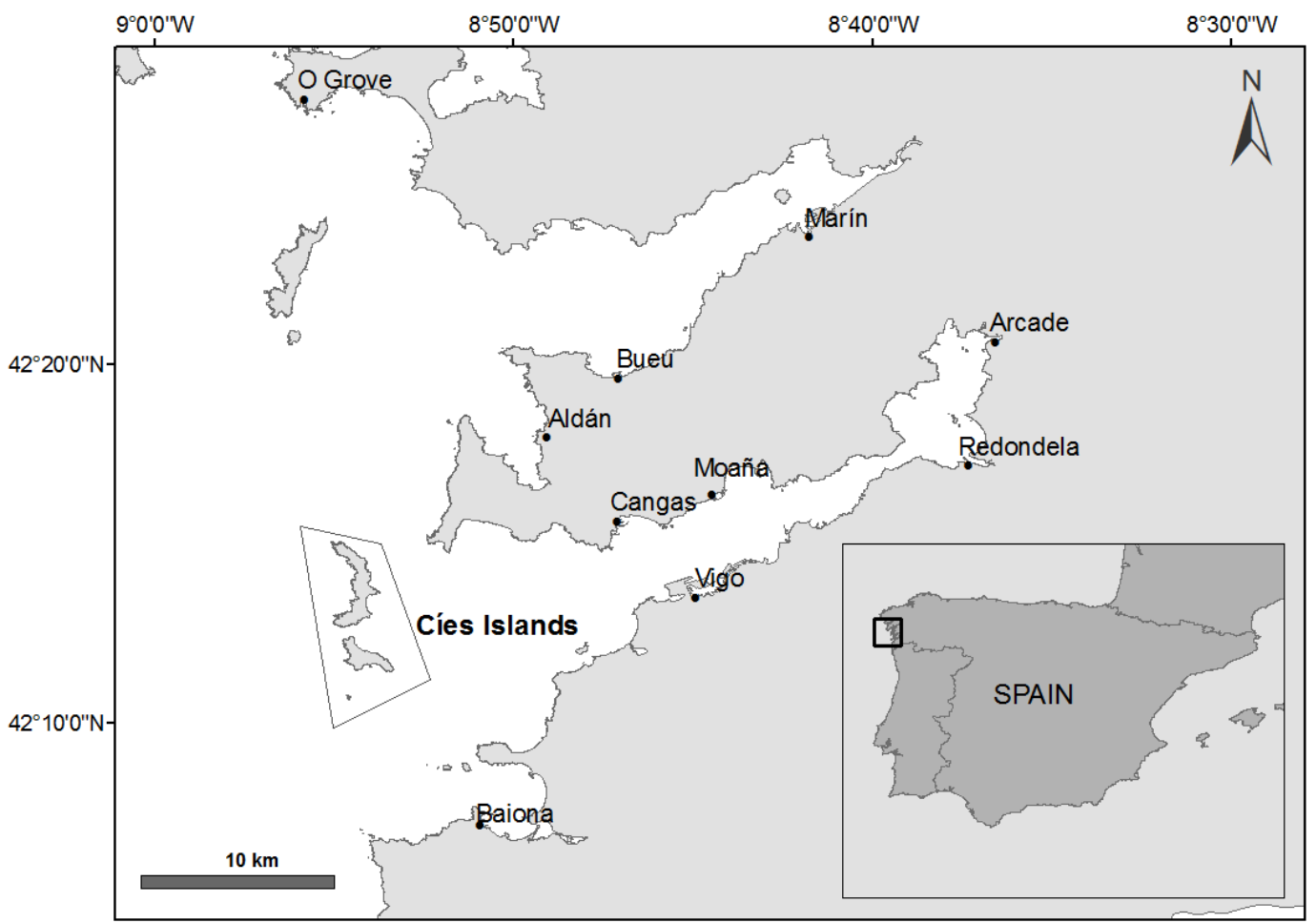

Fig. 1. Study area showing the main fishing organization (“cofradías”) of Ría de Pontevedra (O Grove, Marín, Bueu y Aldán) and Ría de Vigo (Cangas, Moaña, Arcade, Redondela, Vigo y Baiona) and the Marine Park of the Cíes Islands, delimited by its boundaries.

\subsection{Sampling methodology}

Indicators of the economic performance of fishing vessels are often derived from economic data collected in interviews or questionnaires with fishers (e.g. Boncoeur et al. 2000; Long et al. 2008). This approach is useful not only because it allows the economic situation of a fleet to be estimated when the official data are not complete or not collected regularly (Ünal and Franquesa 2010), but also because the fishers are directly involved in the study project and their perception of the economic changes in their activity can be determined.

Data were collected from a sample of the population previously estimated, which was randomly selected (STECF 2009), giving a total of 90 fishers (81 vessel owners, 7 skippers and 2 sailors) interviewed between March and August 2009. Five of the fishermen interviewed were owners of two fishing vessels and they described the economic performance of both vessels. The interviews represented $16.5 \%$ of the artisanal segment $(n=85), 20 \%$ of the polyvalent segment $(n=3)$ and $20 \%$ of the purse seiners $(n=7)$ of the entire Cíes fleet. The sampling-rate range was therefore 16-20\%, making it similar to other studies on this subject (e.g. Cambiè et al. 2010; Van Iseghem et al. 2011). The information requested during the interviews was related to the technical details, costs and production data of fishing activity during 2008. The technical data included information about the crew (number of fishers and the sharing system under which the fishing income was divided among members of the crew and the boat owner) and fishing effort (total number of fishing days by gear and month and their percentage spent in the Cíes Islands). The costs data included the variable costs (fuel, lubricating oil, bait, ice and crates), fixed costs (including dockage, insurance, license fees, maintenance costs required to keep the vessel in working condition and the annual fee for the bank in the case of debt) and investments (type, cost and lifetime of investments). The production data included the total monthly catch and monthly catch by species (in weight, $\mathrm{kg}$ ), the landing price by species (minimum, maximum and mean price in $2008, €$ ) and monthly landings by gear $(€)$. Finally, we asked each owner to estimate the current value of their vessel and the vessel's equipment, in the case that he had to sell it or purchase it in the same conditions. This information was essential for estimating the value of the total invested capital (TC), as suggested by Franquesa et al. (2001).

\subsection{Data analysis}

A set of economic and social indicators was selected according to the guidelines of the European Commission (e.g. STECF 2010) and FAO (FAO 1999) in order to provide a practical and cost-effective way of evaluating the state of the fisheries system in Cíes Islands (Table 1).

The average wage, salary cost, net profit and rate of return on investment were the main indicators of the socioeconomic performance of the fleet, which was closely related to the cost structure of the fishing activity. The salary cost indicates the fisher's income, which varied according to whether the fisher was the skipper, owner or a member of the crew. Therefore, the individual salary was estimated by subtracting the variable costs (VC) from the total income (TI) and then 
Table 1. Economic indicators selected for assessing the performance of the Cíes fleet in 2008 and the equations used for quantifying them.

\begin{tabular}{|c|c|c|c|}
\hline & Type & Description & Equation \\
\hline \multirow{4}{*}{ 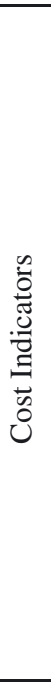 } & $\begin{array}{l}\text { Fixed Costs } \\
\text { (FC) }\end{array}$ & $\begin{array}{l}\text { Administrative costs (AC), } \\
\text { maintenance costs (MC), } \\
\text { depreciation (D) }\end{array}$ & $\mathrm{AC}+\mathrm{MC}+\mathrm{D}$ \\
\hline & $\begin{array}{l}\text { Variable Costs } \\
\text { (VC) }\end{array}$ & $\begin{array}{l}\text { Annual cost of fuel (CF), lu- } \\
\text { bricating oil (LO), bait (BC), } \\
\text { ice (I) and crates (C) }\end{array}$ & $\mathrm{CF}+\mathrm{LO}+\mathrm{BC}+\mathrm{I}+\mathrm{C}$ \\
\hline & $\begin{array}{l}\text { Opportunity Cost } \\
\text { (OP) }\end{array}$ & $\begin{array}{l}\text { Benefits that the owner } \\
\text { could have obtained by in- } \\
\text { vesting their capital (TC) } \\
\text { in an alternative risk-free } \\
\text { investment (national debt). It } \\
\text { is calculated by multiplying } \\
\text { the total capital (TC) by the } \\
\text { average real interest rate (R) }\end{array}$ & $\mathrm{TC} \cdot \mathrm{R}$ \\
\hline & $\begin{array}{l}\text { Average Wage } \\
(\mathrm{AW})\end{array}$ & $\begin{array}{l}\text { Average salary obtained by } \\
\text { each employee, calculated by } \\
\text { dividing the salary cost }(\mathrm{SC}) \\
\text { by the number of crew }(\mathrm{N})\end{array}$ & $\mathrm{SC} / \mathrm{N}$ \\
\hline \multirow{3}{*}{ 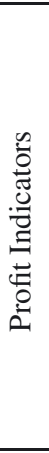 } & $\begin{array}{l}\text { Vessel Physical Productivity } \\
\text { (VPP) }\end{array}$ & $\begin{array}{l}\text { Average production of each } \\
\text { vessel in terms of weight of } \\
\text { landings }\end{array}$ & \\
\hline & $\begin{array}{l}\text { Capacity Physical Productivity } \\
\text { (CPP) }\end{array}$ & $\begin{array}{l}\text { Average production in terms } \\
\text { of weight of landings for } \\
\text { each capacity unit }(\mathrm{GT}) \text { of the } \\
\text { vessel. }\end{array}$ & \\
\hline & $\begin{array}{l}\text { Vessel Productivity } \\
\text { (VP) }\end{array}$ & $\begin{array}{l}\text { Average production in terms } \\
\text { of market value at first sale } \\
\text { for each vessel. It is calculated } \\
\text { by multiplying the VPP by the } \\
\text { landing prices (LP) }\end{array}$ & $\mathrm{VPP} \cdot \mathrm{LP}$ \\
\hline \multirow{3}{*}{ 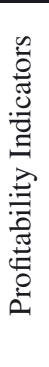 } & $\begin{array}{l}\text { Total Capital } \\
\text { (TC) }\end{array}$ & $\begin{array}{l}\text { Current price assigned to } \\
\text { the vessel and the vessel's } \\
\text { equipment }\end{array}$ & \\
\hline & $\begin{array}{l}\text { Net Profit } \\
\text { (NP) }\end{array}$ & $\begin{array}{l}\text { Difference between } \mathrm{VP} \text { and } \\
\text { all costs (VC, FC), OP and } \\
\text { SC) }\end{array}$ & VP-VC-FC-OP-SC \\
\hline & $\begin{array}{l}\text { Rate of Return on Investment } \\
\text { (ROI) }\end{array}$ & $\begin{array}{l}\text { Percent ratio of yearly net } \\
\text { profits plus the opportu- } \\
\text { nity cost in relation to the } \\
\text { investment. }\end{array}$ & $\mathrm{OP}+\mathrm{NP} / \mathrm{TC}$ \\
\hline
\end{tabular}

assigning the part corresponding to each fisher. The opportunity cost and the fixed costs represent the capital and operational costs, respectively, and need to be given particular attention. The opportunity cost of capital reflects the alternative rate of return if the capital had been invested in the national debt; it was calculated using the interest rate of 2008, which is the difference between the rate for Spanish government bonds and the inflation rate. There is a profit in the economic sense when the yields of the invested capital surpass the opportunity cost. The fixed costs, which include not only the administrative and maintenance costs but also the depreciation, are related to all the investments that are essential for carrying out the fishing activity. Like the opportunity costs, depreciation is an indirect cost and essentially represents the decline in value of the assets. We grouped the types of investment into four main categories: electrical equipment (radar, sonar, etc.), parts of the vessel (engine, winch, vessel hull, etc.), safety material (lifejackets, raft, etc.) and fishing gears. In the present study, the vessels belonging to the same segment using the same fishing gears were considered to have the same kind of investments, and thus similar depreciation. Finally, we estimated the cash flow generated by the fishing activity, not only at vessel and segment level but also at fleet level, by calculating the total incomes (TI), the incomes by species generated by the whole fleet, and those obtained just from fishing around the Cíes Islands. As the exploitation of razor shells (Ensis arcuatus), sea urchins (Paracentrotus lividus), goose barnacles (Pollicipes pollicipes) and clams (Venerupis rhomboides, Venerupis pullastra) (also called "specific resources") in Cíes Islands was regulated through daily quota for the vessels authorized, these plans were subjected to rigorous controls and the official data on catch and landings of shellfish 
Table 2. Technical and operational data per vessel for the three fleet segments of the Cíes fleet in 2008 (mean \pm SE).

\begin{tabular}{llrccl}
\hline $\begin{array}{l}\text { Fleet } \\
\text { segments }\end{array}$ & $\begin{array}{l}\text { Age of vessel } \\
\text { (years) }\end{array}$ & $\begin{array}{l}\text { Length of } \\
\text { vessel }(\mathrm{m})\end{array}$ & $\begin{array}{l}\text { Engine } \\
\text { power }(\mathrm{HP})\end{array}$ & $\begin{array}{l}\text { Number of } \\
\text { crew }\end{array}$ & Fishing days \\
\hline Artisanal & $19.8 \pm 1.7$ & $7.4 \pm 0.3$ & $46.7 \pm 3.6$ & $2.2 \pm 0.1$ & $186.3 \pm 5.5$ \\
Polyvalent & $25.7 \pm 7.2$ & $13.0 \pm 0.5$ & $134.3 \pm 43.2$ & $4.0 \pm 0.0$ & $203.7 \pm 20.5$ \\
Purse seiners & $19.1 \pm 2.1$ & $15.0 \pm 0.8$ & $179.2 \pm 23.5$ & $9.0 \pm 0.5$ & $171.1 \pm 9.3$ \\
\hline
\end{tabular}

Table 3. Indicators of costs, profit and profitability per vessel for the Cíes fleet in 2008.

\begin{tabular}{|c|c|c|c|c|}
\hline & \multirow{2}{*}{ Indicators } & \multicolumn{3}{|c|}{ Fleet segment } \\
\hline & & Artisanal & Polyvalent & Purse seiners \\
\hline \multirow{6}{*}{ 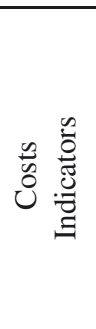 } & Administrative Cost $(\mathrm{AC})(€)$ & 940 & 1967 & 6608 \\
\hline & Maintenance Cost $(\mathrm{MC})(€)$ & 685 & 2400 & 4386 \\
\hline & Depreciation $(\mathrm{D})(€)$ & 6450 & 10578 & 23843 \\
\hline & Variable Cost $(\mathrm{VC})(€)$ & 8919 & 24952 & 54039 \\
\hline & Opportunity Cost $(\mathrm{OP})(€)$ & 1291 & 2202 & 4121 \\
\hline & Average Wage $(\mathrm{AW})(€)$ & 15304 & 9060 & 24685 \\
\hline \multirow{3}{*}{ 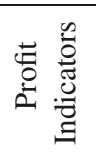 } & Vessel Physical Productivity (VPP) (t) & 13.7 & 25.8 & 355.9 \\
\hline & Capacity Physical Productivity (CPP) (t) & 5.11 & 2.48 & 21.21 \\
\hline & Vessel Productivity (VP) (€) & 63530 & 91522 & 315420 \\
\hline \multirow{3}{*}{ 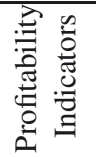 } & Total Capital (TC) (€) & 86078 & 146817 & 274714 \\
\hline & Net Profit (NP) (€) & 6669 & 527 & 26848 \\
\hline & Rate of Return on Investment (ROI) (\%) & 6.8 & 2.5 & 13.2 \\
\hline
\end{tabular}

were considered reliable. Therefore, our method focused on all other demersal and pelagic resources harvested without specific management measures, in order to improve the estimation of their biomass extracted by the Cíes fleet.

\section{Results}

\subsection{Technical and operational characteristics of the Cíes fleet}

The Cíes fleet is composed of a multi-species, multi-métier fishery that operates throughout the year both inside and outside the park. The fishing capacity in terms of engine power, number of crew and length of vessels of the three fleet segments increases from artisanal to polyvalent up to the purse seine vessels (Table 2). The artisanal segment of the fleet is the largest in terms of the number of boats and fishers. The artisanal vessels use a large diversity of fishing gears, including both passive gears, such as traps targeting common octopus (Octopus vulgaris), crabs and shrimps, trammel nets ("miños" and "trasmallo", different from each other for the panel mesh size combinations), gillnets and bottom longlines; and active gears, such as clam dredges, clam rakes, trawl gears targeting cuttlefish (Sepia officinalis), small drift nets targeting sardine (Sardina pilchardus), diving for razor shell and sea urchins and intertidal harvesting for goose barnacles. Although each vessel had a fishing license for an average of four different gears, most of the boat owners interviewed $(42 \%, n=36)$ used just two gears over the year. The main fishing gears used by the artisanal vessels were clam rakes, octopus and crab traps and set nets (trammel nets and gillnets). These fisheries targeted a variety of high-value species, such as clams, octopus and crabs (Necora puber, Maja brachydactyla). Set nets were also the fishing gear the most used by the polyvalent vessels, even though this segment was not particularly representative of the studied fleet ( 15 vessels estimated). The purse seiners of the Cíes fleet targeted mainly small pelagic species, such as Atlantic horse mackerel (Trachurus trachurus) and sardine. These vessels fished up to four days a week in accordance with the law, while artisanal and polyvalent boats fished up to five days, from Monday to Friday.

\subsection{Cost structure}

For the three fleet segments, the variable, fixed, salary and opportunity costs varied in nature and importance. The variable costs were directly related to the number of fishing days (Table 3) and fuel was the most expensive item for all three fleet segments, accounting for $71 \%, 66 \%$ and $74 \%$ of the total variable costs for artisanal, polyvalent and purse seiners, respectively. Although fuel was generally the highest variable cost, its mean price during 2008 increased by around $18 \%$ with respect to 2007 (Ministerio de Industria, Energía y Turismo 2012) and this may have affected the economic performance of the three fleet segments differently. A difference in the cost structure between purse seiners and artisanal vessels was also related to bait, as it was absent for the former and limited to the use of bottom longlines and traps for the latter. Moreover, 
Table 4. Income per vessel (€) obtained with each fishing method $(f)$ and its $\%$ on total revenues for artisanal, polyvalent and purse seine vessels in 2008. Table also shows the part of income generated by the fisheries around the Cíes Islands.

\begin{tabular}{|c|c|c|c|c|}
\hline \multirow{3}{*}{ Fishery $(f)$} & \multicolumn{4}{|c|}{ Mean values per vessel } \\
\hline & \multirow{2}{*}{$\begin{array}{r}\text { Income from } f \\
(€)\end{array}$} & \multirow{2}{*}{$\begin{array}{l}\text { Income from } f / \\
\text { total income }(\%)\end{array}$} & \multicolumn{2}{|c|}{ Part of $f$ income from Cíes } \\
\hline & & & $€$ & $\%$ \\
\hline \multicolumn{5}{|l|}{ Artisanal } \\
\hline Razor shell fishery $(n=17)$ & 43833 & 100 & 30894 & 70.5 \\
\hline Sea urchin fishery $(n=5)$ & 42377 & 63.1 & 22227 & 52.4 \\
\hline Goose barnacle fishery $(n=34)$ & 42793 & 85.4 & 33377 & 78.0 \\
\hline Clam rake $(n=140)$ & 22511 & 44.8 & 11607 & 51.6 \\
\hline Clam dredge $(n=10)$ & 20116 & 38.4 & 7537 & 37.5 \\
\hline Octopus trap $(n=107)$ & 44235 & 56.3 & 29964 & 67.7 \\
\hline Crab trap $(n=92)$ & 27282 & 42.7 & 10365 & 38.0 \\
\hline Shrimp trap $(n=14)$ & 5840 & 18.0 & 5840 & 100 \\
\hline Trammel net "miños" $(n=79)$ & 78732 & 68.9 & 42256 & 53.7 \\
\hline Bottom gillnets $(n=70)$ & 15929 & 23.9 & 9161 & 57.5 \\
\hline Trammel net "trasmallo" $(n=60)$ & 36951 & 71.0 & 18419 & 49.8 \\
\hline Drifting gillnet $(n=31)$ & 14965 & 22.7 & 11681 & 78.1 \\
\hline Trawl gears $(n=26)$ & 10288 & 18.1 & 4998 & 48.6 \\
\hline Bottom longline $(n=29)$ & 20446 & 42.5 & 14990 & 73.3 \\
\hline \multicolumn{5}{|l|}{ Polyvalent } \\
\hline Trammel net "miños" $(n=12)$ & 50823 & 55.5 & 40233 & 79.2 \\
\hline \multicolumn{5}{|l|}{ Purse seiners } \\
\hline Purse seine $(n=35)$ & 315420 & 100 & 210600 & 66.8 \\
\hline
\end{tabular}

crates and ice represented $22 \%$ of total variable costs for purse seiners while these costs represented approximately $6 \%$ for polyvalent and artisanal vessels.

The yearly fixed costs included administrative costs, maintenance costs, the annual fee for the bank in the case of debt, and depreciation of the vessel and equipment. During 2008, the administrative costs were different for the three fleet segments (Table 3). The maintenance costs also differed and it seems that the polyvalent segment spent proportionately more than artisanal vessels and purse seiners, possibly due to the old age of the boats (Table 2). In terms of depreciation, the nets were the most common and expensive investment for the three fleet segments. The engine was also an important type of investment, with an estimated value of around $9533 €$ and a mean lifetime of 11 years for the artisanal vessels, and values of $15000 €$ for the polyvalent vessels and $30000 €$ for the purse seiners, both with lifetimes of around 20 years.

The salary cost is of great social importance, and can vary according to the status of each crew member and for each fleet segment. For the artisanal and polyvalent vessels no difference in wage between the crew members (including the owner) was detected, due in part to the family character of their activity (Freire and Allut 2000). Moreover, in these segments, there was usually no task division and specialization of crew members and therefore all the fishers generally received equal parts. In contrast, the purse seiners had a different work structure, with a clear separation between the tasks of the crew delineating three different jobs and salaries: machinist (27 242€), sailor (17 100€) and skipper (37 299€). This difference was also influenced by the nature of the relationship between the crew members, which was usually business-like and not familiar. Finally, the opportunity cost was estimated using the value of the total invested capital (TC) declared by the owners, which corresponded to the actual value estimated for the vessel including all the engines and the fishing license. For the artisanal segment, the value of capital invested per vessel was estimated at $86078 €$, of which 39\% was fishing licenses. For the polyvalent segment, the invested capital was estimated at $146817 €$, of which $30.6 \%$ was fishing licenses. Lastly, for the purse seiners, the TC value was estimated at $274714 €$, of which $25.1 \%$ was the fishing license. It is worth noting that the fishing licenses of the artisanal segment were more expensive than those of the polyvalent segment and seiners, possibly because they included all the fishing licenses targeting specific resources, such as razor shells, sea urchins and goose barnacles, which are restricted in number. The purse seiners invested more in the vessel's equipment than in fishing licenses, which explains the high number of vessel insurance contracts $(71 \%$, $n=5$ ). The opportunity cost was estimated at $1291 €$ for artisanal vessels, $2202 €$ for polyvalent vessels and $4121 €$ for purse seiners.

\subsection{Economic and financial performance}

The vessel productivity in terms of weight and value of landings increased from artisanal to polyvalent and purse seine vessels (Table 3 ). However, the capacity physical productivity (CPP) showed that the average production (in weight) per gross tonnage for polyvalent vessels was less than that for artisanal vessels. This change in the trend was also reflected in the profitability indicators, which showed a very low profit margin for the polyvalent segment $(2.5 \%)$. The net profit value showed that purse seiners had higher profitability than the other fleet segments, clearly due to the high vessel capacity and the large amount of capital invested, so that this segment could also be defined as semi-industrial. 


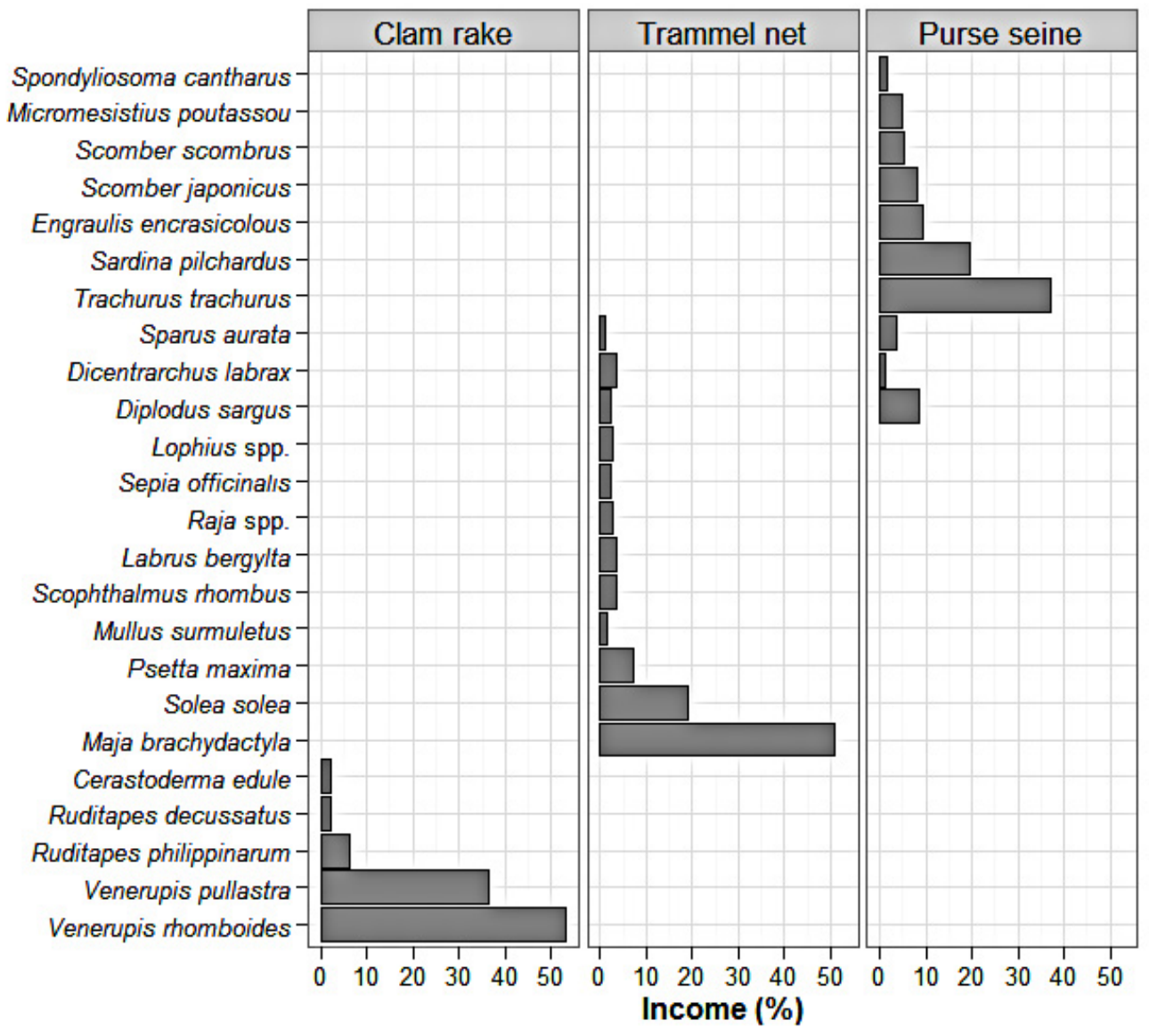

Fig. 2. Income composition per vessel obtained from the sale of the species caught with clam rake (22 $511 €)$, trammel net "miños" (78 $732 €)$ and purse seine (315 $420 €$ ).

The total yearly income per vessel during 2008, as well as the percentage contribution of each fishing gear to the total catch and revenues of the vessel was estimated. Within these percentages, the share of revenues obtained from grounds located around the Cíes Islands was compared to the other fishing areas (Table 4). Our results show that the Cíes Islands is the most important fishing ground for most of the studied fleet in terms of total incomes. For the artisanal fisheries, clam rakes, octopus traps and trammel nets ("miños") were the most common fishing gears used by the artisanal segment and were also the gears used predominantly around the Cíes Islands. Trammel nets were also the main fishing gear of the polyvalent segment, as they were used by 12 fishing vessels. The income composition of the main fishing gears used by the three fleet segments is presented (Fig. 2).

At the segment level, the species that mainly contributed to the total income of the artisanal vessels were common octopus and spider crab (M. brachydactyla), due to their high economic value and also because they were the main target species for the majority of vessels. In fact, although other species, such as goose barnacles, velvet swimcrabs (Necora puber) and common prawns (Palaemon serratus), had a higher selling price, fewer vessels targeted them in comparison with the number targeting the common octopus and spider crab and thus they generated a lower total income for the entire segment. The spider crab was also the most important species caught by the polyvalent segment, while Atlantic horse mackerel and sardine were the main landings for the purse seiners. From the interviews, we estimated the total catch (tonnes) and the related incomes generated by the main target species of the three fleet segments. Results showed that four species (common octopus, spider crab, Atlantic horse mackerel and sardine) produced almost $60 \%$ of the total income from the Cíes Islands (Table 5). Considering the main target species of the studied fleet and the amount of their biomass estimated to come from the Cíes Islands, we calculated that the cash flow generated by the marine park in 2008 was around 16 million euro. This estimate only corresponds to the first sale price of the catches and not to the whole fisheries value chain, which would clearly be much higher, as demonstrated by the price difference between origin and destination of the seafood products (Ministerio de Agricultura, Alimentación y Medio Ambiente 2012).

\section{Discussion and conclusion}

Artisanal vessels and purse seiners are the most highly represented segments of the fishing activity in the Cíes Islands; 
Table 5. Total catch (tonnes) and the related income generated by the sale of the main species caught around the Cíes Islands.

\begin{tabular}{lrrr}
\hline Species & Catch (tonnes) & $\begin{array}{r}\text { Income } \\
\text { (million } € \text { ) }\end{array}$ & \% of total revenue \\
\hline Octopus vulgaris & 577.6 & 2.99 & 18.6 \\
Trachurus trachurus & 2396.6 & 2.80 & 17.4 \\
Maja brachydactyla & 189.0 & 2.33 & 14.5 \\
Sardina pilchardus & 1981.4 & 1.25 & 7.7 \\
\hline
\end{tabular}

however, they clearly have different social and economic impacts. While artisanal vessels play an essential social role in Galician fishing communities and also employ a large number of people, the purse seiners represent a fundamental economic segment because they provide the highest profit per vessel. The polyvalent segment accounted for an estimated 15 vessels and thus does not seem to be a relevant fishery in the marine park. This was possibly due to the high maintenance and fuel costs that may have made this activity economically unsustainable in the study area. In addition, the small sample size of the interviews in this segment may not have been sufficiently representative and therefore the related indicators may have a high degree of uncertainty. The artisanal segment of the Cíes fleet appeared to be economically profitable during 2008, with a ROI around 7\% per vessel. A similar value was estimated for the Galician small-scale fleet between 2001 and 2005 (GarzaGil and Amigo-Dobaño 2008), although the incomes and costs in the cited study were lower than those estimated in our research. This discrepancy could be due to the greater engine power and larger number of crew of our studied vessels, which would therefore have a greater fishing capacity, or the particularly high productivity of the waters around the Cíes Islands. It is likely, however, that the high fuel price in 2008 reduced the profit margin compared with previous years, which could have limited investments in the vessels for 2009. This situation could be favorable from a management point of view because the benefits of the activity would be associated with a limited increase in fishing capacity and capitalization. For purse seiners, the annual catch estimated in the present study was similar to that estimated by Vázquez-Rowe et al. (2011) in Galicia for 2008, a fact that can be considered as indirect evidence of the reliability of our results. The ROI for purse seiners was estimated to be around $13 \%$. This value indicates that this fleet segment performed well economically during 2008, since $10 \%$ is already considered a good result (Tietze et al. 2005). Profitability indicators are particularly useful for assessing capacity levels of fisheries (Ward et al. 2004) and a good economic performance can encourage investment in fishing. It is therefore likely that the purse seiners invested at least part of the benefits in vessel technology, for example, by upgrading their engines and electronic equipment. The investment of capital in vessel improvement would have led to a possible increase in fishing capacity in 2009. In fact, in an open-access regime, excess capacity could occur under a harvesting strategy driven by profit maximization (Nøstbakken et al. 2011) with a consequent difficulty in achieving the long term sustainability of the fishery. Thus, the effect of technological progress and investment need to be taken into account and possibly limited, especially in profitable fisheries (Kirkley and Squires 2003; Ward et al. 2004; Villasante and Sumalia 2010).
For a more comprehensive picture, we compared our results with those estimated for other fleets operating in the northwest Atlantic, such as the Portuguese, French and Irish fleets. The economic indicators, such as income per vessel and operational costs, in the European reports on the economic performance of fisheries during 2006 were of a similar order of magnitude as our data for both small-scale vessels and purse seiners (STECF-SGECA 2008; FRAMIAN 2009). According to the cited studies in the Atlantic, vessels less than $12 \mathrm{~m}$ in length using passive gears had annual incomes ranging between $55000 €$ and $115000 €$ per vessel in 2006. The income value estimated for the artisanal vessels in our study (around $64000 €$ ) fell within this range. Although this segment was composed of vessels that combined mobile and passive gears, set nets and traps were two of the most used fishing gears. Moreover, the common octopus and spider crab were the main species contributing to the total income, so the comparison with vessels using passive gears appears to be appropriate. The annual incomes of the purse seiners in our study (around $315000 €$ ) were also of a comparable order of magnitude to those of other European Atlantic fleets (STECF-SGECA 2008; FRAMIAN 2009). In the case of purse seine vessels, this similarity could also be due to the fact that sardine and mackerel stocks are common for North Portugal and Galicia. Therefore, the artisanal vessels and purse seiners of the Cíes fleet could have, at least in part, an economic structure similar to that of the same segments of other Atlantic fleets. The methodologies applied in our study for assessing and analysing the fishing system would therefore be appropriate for other fleets, such as Atlantic fleets, particularly when the official data are biased and do not indicate the fishing grounds exploited.

The present study describes the economic structure of the Cíes fleet by filling in the gaps in the official information with data collected using an alternative method. It complements the official statistics with new catch data per fishing ground (Cíes Islands in this case), which is essential information for any management plan. Moreover, in multi-species, multi-métier fisheries, the exploitation strategies are not generally reflected in the statistics. Thus, despite the potential inaccuracies stemming from fishermen's declarations, the method proposed can greatly help improve understanding of the different fishing practices, their economic structure and the dependency of the fleet on the fishing area. The indicators generated provide a bridge between objectives and actions (FAO 1999) allowing analytical or policy purposes to be defined (Le Gallic 2002).

Some limitations associated with the economic indicators provided should, however, be taken into account, and managers need to understand that they do not represent all the aspects of fleet productivity. Felthoven and Paul (2004) described some of the limitations of these indicators, for 
example, that they don't take into account the role of the resource abundance or discard level when productivity growth is calculated. In addition, the multispecies nature of the smallscale fishery in Galicia could not be represented completely with the current economic indicators. Since one of the objectives in fisheries economics is to maximize sustainable profit, it is impossible to optimize the yield of each species separately and some compromise is necessary (Cochrane 2000). The ideal situation would be to formulate integrated indicators that are more representative of the complexity of certain fisheries, and which would combine the ecological, economic and ethical aspects of the activity (Hundloe 2000; Shin et al. 2005; Gascuel et al. 2012). However, in the meantime, the indicators provided in this study can be considered representative of the general trend of the economy of our study fleet and can also be used as a reference for decision-makers and a tool with criteria for developing improved regulation strategies. In particular, the use of economic indicators makes it possible to simulate the economic consequences of a range of proposed management options. This kind of simulation has been proposed in a number of studies in which appropriate models have been used to determine the most economically sustainable management scenario (Ulrich et al. 2002; Alban et al. 2004; Merino et al. 2007). In our case study, as the Cíes Islands are not only an important fishing ground, generating around $8.5 \%$ of the regional cash flow arising from the fishing sector (FernándezMacho et al. 2004), but also a marine park requiring conservation measures, the proposed indicators would greatly help in simulating the economic consequences of spatial and effort management. As shown at larger scale levels (Guascuel et al. 2012), this approach can contribute to the evolution of fleetbased management, which reflects the ecological, economic and social pillars of sustainable fisheries.

Acknowledgements. The authors gratefully acknowledge financial support from the Spanish Ministry of the Environment and the European Regional Development Fund (ERDF). We would like to thank the National Marine Park of the Atlantic Islands of Galicia and the "Consellería do Mar" of the Autonomous Government of Galicia ("Xunta de Galicia") for their cooperation. Special thanks to the fishing cooperative "Cofradía de Cangas" and all the fishers involved for the valuable information they provided. Finally, we thank J. Guillén, two anonymous reviewers and the editor B. Milcendeau for their valuable comments and suggestions.

\section{References}

Alban F., Le Floc'h P., Boncoeur J., 2004, The impact of economic and regulatory factors on the relative profitability of fishing boats: A case study of the seaweed harvesting fleet of Northwest Brittany (France). Aquat. Living Resour. 17, 185-193.

Boncoeur J., Coglan L., Le Gallic B., Pascoe S., 2000, On the (ir)relevance of rates of return measures of economic performance to small boats. Fish. Res. 49, 105-115.

Cambiè G., Camiñas J.A., Franquesa R., Mingozzi T., 2010, Fishing activity and impacts along the main nesting area of loggerhead sea turtle Caretta caretta in Italy: overwhelming discrepancy with the official data. Sci. Mar. 74, 275-285.
Cochrane K.L., 2000, Reconciling sustainability, economic efficiency and equity in fisheries: the one that got away? Fish. Fish. 1, 3-21.

FAO, 1999, Indicators for sustainable development of marine capture fisheries. FAO Technical Guidelines for Responsible Fisheries. Food and Agriculture Organization, Rome, $n^{\circ} 8$.

Felthoven R.G., Paul C.J.M., 2004, Directions for productivity measurement in fisheries. Mar. Policy 28, 161-169.

Fernández-Macho J., Gallastegui C., González P., 2004, The social accounting matrix for the Galician fishing sector: what do we learn from it? In: Proceedings of the 2004 EAFE Conference. European Association of Fisheries Economists, pp. 1-39.

FRAMIAN, 2009, Economic analysis of raising de minimize aid for fisheries (MARE/2008/12). Report to EC.

Franquesa R., Malouli I.M., Alarcón J.A., 2001, Feasibility assessment for a database on socio-economic indicators for Mediterranean fisheries. Studies and Reviews. General Fisheries Commission for the Mediterranean. Food and Agriculture Organization, Rome, $\mathrm{n}^{\circ} 71$.

Freire J., Bernárdez C., Corgos A., Fernández L., González-Gurriarán E., Sampedro M.P., Verísimo P., 2002, Management strategies for sustainable invertebrate fisheries in coastal ecosystems of Galicia (NW Spain). Aquat. Ecol. 36, 41-50.

Freire J., García-Allut A., 2000, Socioeconomic and biological causes of management failures in European artisanal fisheries: the case of Galicia (NW Spain). Mar. Policy 24, 375-384.

Garza-Gil M.D., Amigo-Dobaño L., 2008, The profitability of the artisanal Galician fleet. Mar. Policy 32, 74-78.

Gascuel D., Merino G., Döring R., Druon J.N., Goti L., Guénette S., Macher C., Soma K., Travers-Trolet M., Mackinson S., 2012, Towards the implementation of an integrated ecosystem fleetbased management of European fisheries. Mar. Policy 36, 1022 1032.

Griffiths R.C., Robles R., Coppola S.R., Camiñas J.A., 2007, Is there a future for artisanal fisheries in the western Mediterranean? Food and Agriculture Organization, Rome.

Hundloe T.J., 2000, Economic performance indicators for fisheries. Mar. Freshwater Res. 51, 485-491.

Iribarren D., Vázquez-Rowe I., Hospido A., Moreira M.T., Feijoo G., 2010, Estimation of the carbon footprint of the Galician fishing activity (NW Spain). Sci. Total Environ. 408, 5284-5294.

Kirkley J.E., Squires D., 2003, Capacity and capacity utilization in fishing industries. Measuring capacity in fisheries. In: Pascoe S., Gréboval D. (eds.), FAO Fish. Techn. Pap. FAO, Rome n ${ }^{\circ} 445$, pp. $35-56$.

Le Gallic B., 2002, Fisheries Sustainability Indicators: The OECD experience. Joint workshop EEA-EC DG Fisheries-DG Environment on "Tools for measuring (integrated) Fisheries Policy aiming at sustainable ecosystem”. Brussels.

Long L.K., Flaaten O., Anh N.T.K., 2008, Economic performance of open-access offshore fisheries-The case of Vietnamese longliners in the South China Sea. Fish. Res. 93, 296-304.

Losada A., 2000, La política del mar. Políticas públicas y autonomía. El caso de la pesca gallega. Edn. Istmo Col. Fundamentos $n^{\circ} 173$.

Merino G., Karlou-Riga C., Anastopoulou I., Maynou F., Lleonart J., 2007, Bioeconomic simulation analysis of hake and red mullet fisheries in the Gulf of Saronikos (Greece). Sci. Mar. 71, 525535.

Ministerio de Agricultura, Alimentación y Medio Ambiente, 2011, Estadísticas pesqueras. Flota Pesquera. Número de buques pesqueros, por intervalo de antigüedad y C. A. del puerto base. www. mapa.es

Ministerio de Agricultura, Alimentación y Medio Ambiente, 2012, Observatorio de Precios de los Alimentos. www.mapa.es 
Ministerio de Industria, Energía y Turismo, 2012, Precios de venta al público de carburantes. Comparación internacional. http://www. minetur.gob.es

Mora C., Myers R.A., Coll M., Libralato S., Pitcher T.J., Sumaila R.U., Zeller D., Watson R., Gaston K.J., Worm B., 2009, Management effectiveness of the world's marine fisheries. PLoS Biol. 7, e1000131 [doi: 10.1371/journal.pbio.1000131]

Nøstbakken L., Thébaud O., Sørensen L.C., 2011, Investment behaviour and capacity adjustment in fisheries: a survey of the literature. Mar. Resour. Econ. 26, 95-117.

Pauly D., 2006, Major trends in small-scale marine fisheries, with emphasis on developing countries, and some implications for the social sciences. Marit. Stud. (MAST) 4, 7-22.

Shin Y.J., Rochet M.J., Jennings S., Field J.G., Gislason H., 2005, Using size-based indicators to evaluate the ecosystem effects of fishing. ICES. J. Mar. Sci. 62, 384-396.

STECF, 2009, Scientific, Technical and Economic Committee for Fisheries (STECF). Report of the Working Group on the quality aspects of the collection of economic data - methods of calculation of the indicators and sampling strategies (SGECA 09-03). Publications Office of the European Union, Luxembourg. ISBN 978-92-79-15356-3.

STECF, 2010, The 2010 Annual Economic Report on the European Fishing Fleet. In: Anderson J., Guillen J. (eds.), Scientific, Technical and Economic Committee for Fisheries (STECF). European Commission, Report EUR 24554 EN.

STECF-SGECA, 2008, Annual Economic Report 2008, European Commission. Scientific, Technical and economic Committee for Fisheries (STECF), Subgroup on Economic Assessment (SGECA) 02-08, Copenhagen, 21-25 April 2008.

Tietze U., Lash R., Thomsen B., Rihan D., 2005, Economic performance and fishing efficiency of marine capture fisheries. FAO Rome, Fish. Techn. Pap. 482.

Ulrich C., Le Gallic B., Dunn M.R., Gascuel J., 2002, A multi-species multi-fleet bio-economic simulation model for the English Channel artisanal fisheries. Fish. Res. 58, 379-401.
Unal V., Franquesa R., 2010, A comparative study on socio-economic indicators and viability in small-scale fisheries of six districts along the Turkish coast. J. Appl. Ichthyol. 26, 26-34.

Van Iseghem E., Quillérou E., Brigaudeau C., Macher C., Guyader O., Daurès F., 2011, Ensuring representative economic data: survey data-collection methods in France for implementing the Common Fisheries Policy. ICES J. Mar. Sci. 68, 1792-1799.

Vázquez-Rowe I., Moreira M.T., Feijoo G., 2010, Life cycle assessment of horse mackerel fisheries in Galicia (NW Spain): Comparative analysis of two major fishing methods. Fish. Res. 106, 517-527.

Vázquez-Rowe I., Moreira M.T., Feijoo G., 2011, Estimating global discards and their potential reduction for the Galician fishing fleet (NW Spain). Mar. Policy 35, 140-147.

Villasante S., Sumaila U.R., 2010, Estimating the effects of technological efficiency on the European fishing fleet. Mar. Policy 34, 720-722.

Ward J.M., Kirkley J.E., Metzner R., Pascoe S., 2004, Measuring and assessing capacity in fisheries. 1. Basic concepts and management options. FAO Fish. Techn. Pap. $n^{\circ} 433$.

Whitmarsh D., James C., Pickering H., Neiland A., 2000, The profitability of marine commercial fisheries: a review of economic information needs with particular reference to the UK. Mar. Policy 24, 257-263.

Worm B., Hilborn R., Baum J.K., Branch T.A., Collie J.S., Costello C., Fogarty M.J. et al., 2009, Rebuilding global fisheries. Science $325,578-585$.

Xunta de Galicia, 2009, Plataforma tecnolóxica da pesca, rexistro buques. www.pescadegalicia.com

Zeller D., Booth S., Davis G., Pauly D., 2007, Re-estimation of smallscale fisheries catches for U.S. flag island areas in the Western Pacific: the last 50 years. Fish. Bull. 105, 266-277. 